\title{
CATHOLIC WOMEN REDESIGN CATHOLICISM: AN ESSAY IN HONOR OF MARIA JOSE ROSADO NUNEZ
}

\author{
Mary Elizabeth Hunt*
}

\begin{abstract}
This essay explores how Catholic women have changed Catholicism as a culture, if not so much the institutional church, in the years between 1970 and 2020. Catholic women have not endeared ourselves to Catholic hierarchs; in fact many dislike and fear us. But we have saved lives, spiritual as well as physical, by providing solid opposition and creative alternatives to the institutional church. A redesign of Catholicsm begins with the culture and ethos. Catholic women envision it as a global movement rooted in particular cultures, united by values of love and justice, open to the wisdom of many religious traditions, and structured to provide ministry and meaning through cooperative, horizontally organized communities. While there has been progress, more work remains to be done.
\end{abstract}

\section{INTRODUCTION}

Maria José Rosado Nunez is a deeply respected and beloved colleague in struggles for women's well-being, especially in the area of reproductive justice. Her decades of creative, fearless, and pioneering work are a legacy for Brazilians as well as for other justice-seekers throughout the world. As a highly skilled sociologist, someone who is deeply informed on theological, philosophical, artistic, and cultural issues, Zeca, as she is known to all, is a unique and valued collaborator.

We met decades ago through Catholics for a Free Choice as it was known in those days, as well as in international feminist theological circles. I have had the privilege of collaborating with her and the wonderful team at Católicas por el Derecho a Decidir over the years. What

* Mary E. Hunt, Ph.D., is a feminist theologian who is co-founder and co-director of the Women's Alliance for Theology, Ethics, and Ritual (WATER) in Silver Spring, Maryland, USA. A Catholic active in the women-church movement, she lectures and writes on theology and ethics with particular attention to social justice concerns.

Mandrágora, v.26, n. 2, 2020, p. 79-93 
fabulous work they do! I have enjoyed her friendship and hospitality. I look forward to many more years together in a world sorely in need of such sisterly connections. I am but one of her many friends who rise to thank and applaud her on this special birthday.

\section{CATHOLICISM}

I focus critically on Catholicism because it underlies Zeca's life story. Educated in a Catholic milieu, spending years in a Catholic religious order, and joining her life with a fine former Jesuit priest, are important aspects of her life. But more tellingly, for Zeca, as for so many Catholics, the deeply held values of love and justice that issue in sacrament and solidarity are the parts of Catholicism that she took seriously. I do not refer in the first instance to church sacraments. Rather, she developed and lives out an appreciation of the sacred aspects of all forms of life. Her work has been dedicated to improving options for those who have very few, sharing resources with the broader community, and putting her intellectual and organizational efforts into creating space for more people to thrive. That approach, and not the institutional church's, describes a 'Catholic' approach in postmodernity.

Some may consider it a waste of effort to bother at all with the institutional Roman Catholic Church whose dust many of us have long kicked from our sandals. But it would be irresponsible to ignore Catholicsm which, like all religious traditions, has power for good, but especially because of the Catholic institution's pernicious patriarchal propensity to do great harm. It would be to leave unanalyzed a major reason why women, especially poor and marginalized women, have no access to effective, economical birth control or abortion. It is why lesbian, bi, trans women and other queer people are discriminated against by laws whose roots and justification lie in institutional Catholicism's (im)moral teaching.

To ignore this institution, even though by most measures it is on the decline, would be naïve if we are serious about social change. The institution still plays a role in society, often to baptize and confirm, to confer sacred legitimacy on the oppression of women. That is unacceptable. Some of us who know the church well assume our responsibility to eradicate such injustice. Hence, we undertake a redesign of the tradition. 
In this essay, I look at how Catholic women have changed Catholicism as a culture, if not so much the institutional church, in the years that Zeca and I have been involved, mainly between 1970 and 2020. In that fifty year period following the Second Vatican Council, Catholic women, including Zeca and her academic and social change colleagues have played a key role. We have not endeared ourselves to Catholic hierarchs; in fact, many dislike and fear us. But I imagine that we have saved lives by providing solid opposition and creative alternatives to the institutional church.

Those result in a redesign of Catholicsm beginning with the culture and ethos. We envision it as a global movement rooted in particular cultures, united by a commitment to values of love and justice, open to the wisdom of many religious traditions, and structured to provide ministry and meaning through cooperative, horizontally organized communities. While we have made progress, we are far from the mark.

The problem is not simply that the Roman Catholic Church opposes women's full humanity and well-being. It is that the same apparatus defends indefensible crimes of clergy sexual abuse and episcopal cover-up. The same institution seeks to manipulate global consensus on vital issues, and continues to support a monarchical way of governing. Despite some useful social interventions, like Pope Francis' encyclical Laudato Si' on the environment, there is always an asterisk: this could have been so much better if it had reflected women's experiences. In the case of Laudato Si', the effort is marred by the fact that the ban on birth control, a key component in global climate justice, is left in place thereby weakening the force of an otherwise useful document.

By most measures, the institutional Roman Catholic Church, and some would argue Catholic culture, has not changed at all in fifty years. Women are not ordained. In some dioceses girls cannot even be altar servers. Moral theology teachings on birth control, abortion, and same-sex love remain mired in misinformation and discrimination. Few women have any jurisdiction on matters of church governance even though there are a few women now in leadership positions (Celia WEXLER, 2020). But the exceptions prove the rule, namely, that fully half of the world's billion Catholics still have no say in the decision-making of the institutional church. 
However, Catholic power has not endured for two thousand years by chance. The ability of the institution to coopt those who resist its ways is legendary. For example, in what was recently heralded as a step forward, a woman was named as an Undersecretary of State (VATICAN NEWS, 2020). Her portfolio includes the United Nations where the Vatican is notorious for enlisting conservative countries to form coalitions to thwart consensus on women's reproductive health matters.

The appointment of a woman to this post mirrors actions of twenty-five years earlier when the Vatican sent its delegation headed by a woman to the Fourth United Nations Conference on Women in Beijing (1995) (Ian JOHNSON, 1995). The results were disastrous for women worldwide. The move proved how deft the Vatican can be in maintaining its power, even to the point of letting a woman lead a delegation that heretofore would have been led by a clergyman. There are women like Mary Ann Glendon, who led the delegation, willing and very capable of doing so even though their views are anti-feminist. The result is a cosmetic change in gender but a continuation of the same anti-feminist ideology. The Vatican is clever and it stops at nothing to enlist women to support it.

Despite these depressing realities, I find the impact of Zeca and other feminist Catholics to be profound and long lasting. The Roman Catholic Church will never be the same again now that women all over the world are wise to its ideology and treachery.

I will explore three areas where this is obvious: membership, moral theology, and ministry.

\section{MEMBERSHIP}

Religious membership is hard to measure. Baptismal records and not parish membership are traditionally cited to show how many Catholics there are in the world. Numbers hover around 1.3 billion or roughly $17 \%$ of the world's population (HOLY SEE PRESS OFFICE, 2019). But the numbers also indicate that while Catholicism is on the rise in Asia and Africa, this is not the case in Europe or the United States which are large donor nations. Oddly, Latin America is lumped with North America in Vatican statistics with the stark admission that the Catholic percentage 
of the population in the southern countries is several times that of the northern countries throughout the Americas. The Vatican admits to a rapidly shrinking number of male priests.

Baptismal statistics are misleading. While they no doubt represent a snapshot of something that happened, albeit many years ago for some people, they do not convey the reality of many people leaving the church which is so prevalent today especially in western and northern countries. So while baptismal statistics may show one trend, on the ground observations tell another story. For example, in the U.S., the largest single denomination is Catholic (David MASCl; Geogory A. SMITH, 2018). But the "Pew Research Center's 2014 Religious Landscape Study... found that the share of Americans who are Catholic declined from 24\% in 2007 to 21\% in 2014" (David MASCl; Geogory A. SMITH, 2018, $s / n)$. That is not trivial, especially in a country that makes a substantial contribution to the Vatican's coffers. Likewise, in Brasil numbers of Catholics has dropped by millions (Kenneth RAPOZA, 2016). Of course there are many reasons for this, including the rise of some evangelical and Pentecostal groups. But the exodus related to women-focused factors plays a large role in all of these declines.

Why do people leave the Roman Catholic Church? First, both women and men are disheartened and disedified by the male-only leadership and official ministry of the church. This issue has been in conversation for over fifty years so there is little new to say about it. Either women, LGBTIQ, and married people are ordained, or church structures change such that the clergy/lay hierarchy is flattened. There is no other choice-full inclusion or structural change. The rapid proliferation of house churches and small base communities which are independent of any Catholic structure proves that 'Catholic' now has many forms, the institutional expression being just one. People are not waiting for Rome. This is a cultural shift.

The problematic issue is that only ordained clerics have jurisdiction or decision-making power, and lay people do not. So in order to create egalitarian forms of community, many more people need to be ordained or the whole system needs to be replaced. I do not see either of these scenarios happening anytime soon, nor do millions of other people who 
have left the church. Catholic women, as will be evident below, simple go ahead and engage in ministry. Many people prefer the women-led communities to the male-led ones especially in an era of clergy sexual abuse and cover-up, all of which they consider Catholic. This is change.

Second, many people who leave, and even some who stay, reject the institution's teachings on birth control, abortion, divorce, and same-sex love as injurious to themselves and their children. The problem is two-fold: the teachings themselves are out of step with contemporary Catholics' experiences and commitments on the one hand, and on the other hand, the duplicity with which these particular issues are chosen and handled scandalizes many people.

For people to be told publicly that using birth control is wrong, and to be told privately by priests to use their own judgement is an approach that was common when the anti-birth control encyclical Humanae Vitae appeared in 1968. The priests are afraid for their own ecclesial careers. But it is women who bear the disproportionate burden in these cases, especially if they do not use contraception and have to deal with an unintended pregnancy. So while the teaching is outmoded, the method of transmission is simply disgusting.

The same duplicitous dynamic plays out now as gay priests, some of whom are sexually active, preach against same-sex love, calling it sinful. Young people pay the price for this charade; many attempt suicide because of the mistaken notions they are taught that their sexual orientation is disordered and their sexual activity is evil. Catholics recognize and call out these mistaken policies. But many are just as concerned about the deceptions which are increasingly being made public.

Third, people leave Catholicism because they have many other good religious options. Small base communities or house churches, liberal Protestant denominations with a focus on sacraments like the Lutheran and Anglican churches which include women in leadership and ministry, and which involve members in decision-making are quite attractive to Catholics who seek the same. Traditions like Buddhism that resonate with Catholicsm in terms of a rich spirituality are among the many choices in the spiritual marketplace. Catholics need not confine themselves to one tradition; one can be a Buddhist Catholic or a Catholic Anglican, for example. 
Feminist scholars in religion have explored many wonderful Goddess, Wiccan, Pagan, and Indigenous groups that provide inspiration for some postmodern people. They have found deep parallels to things Catholic, for example, some Marian churches having been built on ancient Goddess sites. There is simply no comparison in terms of healthy, useful spirituality from these sources and what institutional Catholicsm that actively discriminates against women offers.

Increasing numbers of people identify as 'nones' as in 'none of the above' when it comes to signaling religious preference, preferring in many cases to be spiritual but not religious. All of these options are real and available, respectable and fulfilling. It is amazing that Catholicism has not lost more people in its resistance to change.

Another reason why people are leaving Catholicsm, especially in European countries like Germany and Switzerland where they are bound to pay church taxes, is because they do not want their money used to oppress people, especially women of reproductive age. They have the option to petition formally to leave the church. Many do despite the fact that they can then no longer be employed by a Catholic agency or buried in a Catholic cemetery. I do not know how scrupulously such actions are reported from the various countries to the Vatican. Even if reporting is accurate, I doubt that the Vatican gives a lot of thought to subtracting these numbers from global membership statistics.

All of these and other reasons reflect the impact of critical feminist work in religion that has made deep inroads into the psyches and spirits of many Catholics. No longer can Catholics be lied to or deceived. Women theologians, canon lawyers, biblical scholars, and ministers contribute to fundamental changes of thought and practice. The institutional church continues to resist such change. Meanwhile, its dwindling number of adherents increasingly think for themselves setting a trajectory in the direction that feminist Catholics are modelling.

\section{MORAL THEOLOGY}

Moral theology is a shaping force in Catholicsm. This is not because it is always useful, but because the Roman Catholic Church is one of the few institutions in society that makes universal ethical claims to 
which people both within and outside the church pay any attention. Some of the claims, such as opposition to the death penalty and encouragement of an eco-friendly future are helpful. But the claims on reproductive health, particularly the opposition to birth control and abortion, as well as the anti-LGBTIQ teachings, are deeply problematic. The lack of serious scientific input and dearth of different voices and views in the conversation consigns the institution's teachings to the dust bin of history.

The teachings are dubious in themselves and dangerous in the impact they have on laws and regulations in many countries. It is not an overstatement to say that women have lost their lives because of Catholic teachings on birth control. They have been prohibited by laws based on Catholic teaching in some countries from procuring contraceptives legally. For the same Catholic-caused reason, some women have died from having abortions in unsterile and unsafe conditions. Legal, accessible, sanitary options are simply not available, especially to poor and young women who do not have the means to circumvent the laws that are available to many wealthier and older women.

Women scholars and activists have produced healthy, inclusive, ethical alternatives that now ground women's reproductive justice. Zeca and colleagues at CDD in Brasil have been in the forefront of this movement which involves both theological and legal matters. These are Catholic efforts and result in new Catholic ways of being. This is what change looks like.

Opposition to Humane Vitae still echoes. Catholic feminist theologian Rosemary Radford Ruether wrote some of her first work in contemporary theology on birth control (Patricia MILLER, 2014). She was a classics scholar and Early Church expert by training, but the realities of being a Catholic woman of child bearing age participating in a church that caused existential problems was enough to jumpstart her brilliant career as a theologian, ethicist, and church historian. She read early Patristic texts by the so-called Fathers of the Church (Origen, Tertullian, etc.) though a feminist lens, calling out the misogyny from early on. Rosemary was a longtime board member of Catholic for a Free Choice and a frequent contributor to their periodical Cons- 
cience. She is a staunch public supporter of LGBTIQ+ people who has done a great deal through scholarship and activism to create this new Catholic culture.

Mary Daly, feminist theologian and philosopher, came from the Catholic tradition. She, too, did foundational work that laid the groundwork for the demise of patriarchal Roman Catholicsm. Her simple, brilliant insight, "If God is male, then the male is God." was the beginning of the end of religiously sanctioned male privilege (Mary DALY, 1973).

It is impossible to overestimate the power of feminist studies in religion in the de-construction of Roman Catholicsm. Feminist scholarship in history, biblical studies, liturgical practices, inclusive language, relations with world religions, pastoral care and counselling, ethics, the religious arts, and so many other areas of inquiry has changed the intellectual landscape. Women are learning not only to think for themselves, but to reject the imposition of malestream knowledge.

Many have no concern whether their intellectual and spiritual production is approved by the Roman Catholic Church. But given the sources and the backgrounds of the scholars, such work can legitimately be claimed 'Catholic' by those who wish lest we cede all such authority to the institution. This is part of the overhaul or redesign I have in mind which blurs the lines between institutional Catholicism and emerging Catholic culture.

Abortion is a key ethical issue for Catholics. It is often the touchstone of orthodoxy for those who may take issue with exclusion of women from ordination, the ban on birth control, and many anti-LGBTIQ issues. Still, some cannot quite embrace women's right to reproductive justice. So it is no surprise that the early feminist Christian work on abortion was not by Catholic feminist scholars despite their erudition. Nor had many of the best and brightest Catholic women been siphoned off into ordained ministry as happened early on when some Protestant denominations began to ordain women leaving fewer to pursue academic careers.

Rather, it came from Presbyterian scholar activist Beverly Wildung Harrison. She was very knowledgeable about the Catholic natural law tradition and deeply connected with Catholic feminist work in ethics 
including that of Margaret Farley'. In her landmark book, Our Right to Choose: Toward a New Ethic of Abortion, Beverly Harrison laid out the contours of a Christian pro-choice perspective (Beverly Wildung HARRISON, 1984). She singled out women's moral agency and women's bodily integrity as the foundations for such a position. By this she meant that women making choices is a moral good, even if every choice a woman makes is not good. And, the unique relationship of a fetus to a pregnant woman relies first and foremost on the fetus being part of the woman's body. Thus the woman's well-being, and not simply the well-being of the fetus, is part of the moral equation.

This analysis changed the discourse, including among Catholic feminists, from whether abortion was a sin or not, whether fetuses were persons, whether fetus or woman had priority and other erroneously framed questions to the primary concern for women's well-being in the complicated reality of pregnancy in a racist, sexist, economically unjust world.

Catholic pro-choice positions tended to be developed not so much by individual theologians or ethicists as by groups and organizations. This is a pivotal role that Catholics for Choice groups around the world played in the development of a growing body of scholars, activists, legal workers, and ministers who took special responsibility for dismantling the strong Catholic opposition to abortion based on misogynistic worldviews. Today, to be a pro-choice Catholic is no longer a contradiction in terms. It is a statement of fact that reveals just how many ways there are to be Catholic beyond the path of the institutional church. Of course persons holding such views are variously demeaned and dismissed by the hierarchy as Brazilian theologian Ivone Gerbara experienced, but there is simply no putting the toothpaste back in the tube. Pro-choice Catholics are Catholics.

It is useful to note that Ivone's leadership on eco-feminism is acknowledged worldwide. Luckily, she has not confined her scope to the

Margaret Farley, a Sister of Mercy and Professor at Yale Divinity School, was one of the signers of A Catholic Statement on Pluralism and Abortion, an ad placed in the New York Times in 1984 acknowledging a variety of Catholic views on abortion including those who are pro-choice. She was later sanctioned by the Vatican for her book Just Love: A Framework for Christian Sexual Ethics. New York: Continuum, 2006. The focus of their criticism was her acceptance of same-sex marriage as a moral good and her frank acknowledgement that masturbation is not morally harmful. 
Catholic community, but understands in feminist terms that ecological destruction is a raging danger far beyond the capacity of any group alone to cope with it. Pity that Pope Francis did not invite her to co-write Laudato Si'. It would have been a far more effective document if she had brought her 'catholic' and Catholic feminist sensibilities to it.

Same-sex love is another such example of a redesign of Catholicsm. As with abortion, after reams of scholarship, hundreds of meetings, conferences, press statements, and the like there is simply no way to deny the reality of LGBTIQ Catholics, their friends and allies. Feminist theologies were the foundation of many queer approaches to religion including Catholicsm². While the institutional church wails and gnashes its collective teeth, the non-acceptance of its position is obvious by the many self-identified Queer Catholics. The duplicity of its many gay, some sexually active, clergy trying to sell a defective moral product is a pattern we know well.

These ethical issues have changed and developed over time such that commonly held views on birth control, abortion, same-sex love, and the like are increasingly normative among Catholics. This is true both of those who continue to participate in church life and those who do not, meaning it is a shift in Catholic culture writ large. Such is a significant change.

\section{MINISTRY}

No issue has been more emblematic of Catholic patriarchy than the non-ordination of women (Elisabeth SCHÜSSLER-FIORENZA; Hermann HÁRING, 1999) ${ }^{3}$. The discussions ad nauseam in the past fifty years have

\footnotetext{
Marvin M. Ellison and Judith Plaskow, Editors, Heterosexism in Contemporary World Religion: Problem and Prospect, Cleveland: The Pilgrim Press, 2007. See especially Mary E. Hunt, "Eradicating the Sin of Heterosexism" pp. 155-176. See also, Mary E. Hunt, "Just Good Sex" in Good Sex: Feminist Perspectives from the World's Religions, edited by Patricia Beattie Jung, Mary E. Hunt and Radhika Balakrishnan. New Brunswick, New Jersey: Rutgers University Press, 2001, Ch. 11, pp.158-173. In the same volume, Catholic feminist ethicist Patricia Beattie Jung's Ch. 6, "Sanctifying Women's Pleasure" adds an important dimension to the conversation on pleasure. This early collection reset the question from women not eligible for ordination on patriarchal terms to the fact of women's "non-ordination" by church officials and how it was caused by and resulted in a variety of power-related issues.
} 
resulted in no validly and licitly ordained women deacons, priests, or bishops. Even the recent cry from the people of the Amazon region to extend ordination beyond the narrow circles of vowed celibate men was passed over. They asked for bread and got stones (Matthew 7:1).

The institution continues to dither about the diaconate, setting up a second commission to study the question after the first commission, as one might expect from its diverse make-up, failed to find consensus (Phyllis ZAGANO, 2020)4. Meanwhile, women priests are now ordained in groups like the Roman Catholic Womenpriests, the Association of Roman Catholic Women Priests, the Old Catholic Church, and in many small base communities. The Vatican does not recognize these ordinations despite the women's claims to Apostolic Succession. In some instances, the Vatican has become so distraught as to excommunicate the women involved. But a quick survey of Catholics involved in worship and community life with these women in leadership shows that they readily identify their ministers as Catholic priests. That genie is out of the bottle.

Women from Catholic backgrounds are being ordained in record numbers in many Protestant denominations. For example, in the United States, the United Church of Christ, the Lutheran Church in America (LCA), the Episcopal Church (part of the worldwide Anglican communion), and the Unitarian Universalist Association count many women from Catholic backgrounds in their clergy ranks.

Without negating the women's choices to change denominations, some report that they still 'feel' Catholic, are informed by Catholic values and liturgical sensibilities. It is increasingly common to refer to them as Catholic women who happen to be ordained, and full participants, in another tradition as well. While this may seem to be a contradiction in patriarchal thinking, it is perfectly normal, just of greater complexity than institutional thinkers seem capable of. Ordained Catholic women of this sort cannot be denied as a reality because they do not conform to previous exclusivist, binary thinking.

There are many new expressions of church in which new models of feminist ministry are developing. For example, in the Women-Church movement, small feminist base communities commonly rely on shared

Dr. Zagano served on the first Commission for the Study of the Diaconate of Women. 
leadership thus passing over the matter of ordination entirely. The theology of Eucharist in such communities is not dependent on a biologistic sense of the sacred mysteries confected by a priest intermediary between the community and the Divine. Rather, it is based the shared sacredness of people gathered to give thanks and live out commitments to engage in solidarity work.

All of these issues are the fruit of decades of scholarship and practice, but they combine to promote a different sort of Catholicism-one that is inclusive, welcoming of all at the Table, and part of wider global religious efforts to find common ground to work for the common good. It is a far cry from the morally cramped institutional church's busy efforts to circle the wagons, create a leaner, meaner church in which even many who want to identify as Catholic, and less those who do not, are made to feel unwelcome. Catholic feminists will have no part in such travesties. We have created and will continue to create ample alternatives.

\section{CONCLUSION}

In light of the changes in membership, new understandings of moral theology, and a wide variety of ministerial options, it is clear that Roman Catholicsm will never be the same again. What is emerging does not prioritize Rome as the center of the Catholic universe. Instead, many cultures and regions are encouraged to find their own ways, to practice as befits the pastoral needs of their people. That the Amazon Synod came back empty-handed, ignoring the clearly and deeply expressed needs of people in that region, means that anyone who holds out hope for much change in the institution will wait a long time. In a world plagued by a pandemic, fraught with racial, economic, and ethnic exploitation, and in serious jeopardy of being destroyed both by the possibly of nuclear war and the increasing ecocide, there is no time to wait.

Zeca and colleagues can be proud of the radical changes through which we have redesigned fundamental aspects of the Catholic tradition. After two millennia of toxic male theology and leadership, we are offering wholesale changes in myriad forms. The extent to which we are personae non gratae in official ecclesial circles is one indication of our 
impact. We can take delight in the fact that many people, mostly women but increasingly others as well, have found their way to reproduce health and justice, to new ways of being religious on their own terms, and to new, expansive, multi-faceted forms of spiritual community.

To Zeca, I offer a heartfelt "Obrigada" and a hearty toast, "Ad multos annos." Together with many colleagues, we continue the redesign work with vigor and with the satisfaction of knowing that many women (and men) will have healthier, happier, and more productive lives because of our efforts.

\section{REFERENCES}

DALY, Mary. Beyond God the Father: Toward a Philosophy of Women's Liberation. Boston: Beacon Press, 1973.

ELLISON, Marvin M.; PLASKOW, Judith (Eds.). Heterosexism in Contemporary World Religion: Problem and Prospect. Cleveland: The Pilgrim Press, 2007.

HARRISON, Beverly Wildung. Our Right to Choose: Toward a New Ethic of Abortion. Boston: Beacon Press, 1984.

JOHNSON, Ian. Vatican adopts a softer line in opposing U.N. women's conference declaration. September 16, 1995. Available on: < https://www.baltimoresun.com/news/ bs-xpm-1995-09-16-1995259075-story.html >.

HOLY SEE PRESS OFFICE. Presentation of the Pontifical Yearbook 2019 and the Annuarium Statisticum Ecclesiae 2017, 06.03.2019. Available on: < https:/press.vatican.va/ content/salastampa/en/bollettino/pubblico/2019/03/06/190306b.html >.

MASCI, David; SMITH, Gregory A. 7 facts about American Catholics. Pew Research Center, October 10, 2018. Available on: < https://www.pewresearch.org/fact-tank/2018/10/10/7-facts-about-american-catholics/ >.

HUNT, Mary. Eradicating the Sin of Heterosexism. In: ELLISON, Marvin M.; PLASKOW, Judith (Eds.). Heterosexism in Contemporary World Religion: Problem and Prospect. Cleveland: The Pilgrim Press, 2007, p. 155-176.

. Just Good Sex. In: JUNG, Patricia Beattie; HUNT, Mary E.; BALAKRISHNAN, Radhika (Eds.). Good Sex: Feminist Perspectives from the World's Religions. New Brunswick: Rutgers University Press, 2001, p.158-173.

JUNG, Patricia Beattie. Sanctifying Women's Pleasure. In: In: JUNG, Patricia Beattie; HUNT, Mary E.; BALAKRISHNAN, Radhika (Eds.). Good Sex: Feminist Perspectives from the World's Religions. New Brunswick: Rutgers University Press, 2001, ch. 6.

MILLER, Patricia. The Story Behind The Catholic Church's Stunning Reversal On Contraception. June 5, 2014. Miller reports on Rosemary Radford Ruether's early work 
on birth control. Available on: < https://religiondispatches.org/the-story-behind-the-catholic-churchs-stunning-reversal/\#: :text=In\%201964\%2C\%20another\%2obudding\%20 theologian\%20named\%20Rosemary\%20Radford,into\%20the\%2oliving\%20rooms\%20of\%20 Main\%20Street\%20America >.

RAPOZA, Kenneth. Catholic Shrinkage: has Brasil Given Up on Jesus? Forbes, December 27, 2016. Available on: < https://www.forbes.com/sites/kenrapoza/2016/12/27/brazil-jesus-catholic-datafolha-survey/\#2812a9917609 >.

SCHÜSSLER-FIORENZA, Elisabeth; HÁRING, Hermann (Eds.). Non-Ordination of Women and the Politics of Power, Concilium, 199/3. London: SCM Press, Maryknoll, NY: Orbis Books, 1999.

VATICAN NEWS. Pope appoints woman under-secretary in Vatican Secretariat of State. Jan. 15, 2020. Available on: < https://www.vaticannews.va/en/vatican-city/news/2020-01/ pope-appoints-woman-undersecretary-in-secretariat-of-state.html >.

WEXLER, Celia Viggo. Pope Francis put a woman in a top Vatican role. It shows how little power Catholic women hold. January 21, 2020. Available on: < https://www.nbcnews. com/think/opinion/pope-francis-put-woman-top-vatican-role-it-shows-how-ncna1119661 >. ZAGANO, Phyllis. Women: Icons of Christ. Mahwah: Paulist Press, 2020.

Submetido em: 6-8-2020

Aceito em: $23-10-2020$

Mandrágora, v.26, n. 2, 2020, p. 79-93 